\title{
TRANSFORMATION OF INTERNATIONAL BUSINESS SERVICES INDUSTRY IN LITHUANIA
}

\author{
Neringa Langviniene ${ }^{1}$, Jurgita Sekliuckiene ${ }^{2}$ \\ ${ }^{1,2}$ Kaunas University of Technology, Lithuania \\ cross $^{\text {ref }}$ http://dx.doi.org/10.5755/j01.em.18.2.4088
}

\begin{abstract}
International trade in services is a rather scarcely analysed phenomenon because of the nature of the services. They are seldom exported because of the impossibility to transport, the necessary contact guarantee between the provider and the consumer, and other services characteristics. The international business services usually make a small part of all services export, especially from the less developed, developing and transforming countries. The developed economies are exclusively identified as the exporters and providers of such business services as accounting, management consultations, architectural and technical and trade-related services'. Lithuania is known in the market of the EU as the transport, sometimes as the tourism, but not as the business services provider. There are a few factors, which enable to develop the Lithuanian business services sector successfully enough, namely: developing the economy, increasing competition and attracting more interest of foreign investors.

The aim of the paper is to disclose the changes in the Lithuanian international business services industry.
\end{abstract}

The type of the article: Research report.

Keywords: international business services; international trade; services industry; transformation of services in Lithuania.

JEL Classification: F23, O14, R11.

\section{Introduction}

Introducing the problem. Recent research (Dixel, et al., 2008; Love \& Lattimore, 2009; Cattaneo, 2010) demonstrated growing interest in the international trade in services. The attention increased even more after the liberalization of the trade of business services globally. The liberalization of services encouraged the foreign services providers to search for the possibilities to enter new markets and to internationalize their activities (Hertel, et al., 2000; Karsenty, 2000; McGuire, 2002). The Services directive, enabling to liberalize the services trade in the EU area, as well as attempts of the WTO (World Trade Organization) are successful steps in the services' trade development strategy and opens more possibilities to the EU services'suppliers (Kelsey, 2008).

Developing the background. The specifics of the international services is still scarcely discussed in the scientific literature, because the service as an object for the trade internationally was identified much more later (Love \& Lattimore, 2009; Spring \& Araujo, 2010; Jansen \& Stokman, 2011). The nature of the services (as well as the local ones) defines that the customer and the supplier should meet each other in order to produce and (or) to consume the service. Not always it is beneficial because of the geographical distance, the economy's scale and scope. Alexander, et al (2007) surveys showed that cultural differences are also very important barrier for international trade in services. However, a rapid implementation of the ICT, the electronic commerce enables to avoid the characteristics of the services, which were earlier evaluated as the barriers for the international trade. Opening of borders between countries reduce the influence of culture, too. Besides that, nobody discusses that the services are unique and not all of them could be tradable abroad because of their characteristics, the lack of competitive advantages compared to the local providers, etc. (Bhagwati, 1987; Cattaneo, et al., 2010). Preferences to the local products and 
services could limit the wish to enter the new market. The interest of the authors, who analyse the international services specifics, is related more to the commercial services, which are tradable abroad (Bhagwati, 1987; Cattaneo, et al., 2010) than to non-commercial services.

One of the most rapidly growing services at the international market is other business services (International Trade Statistics, 2013). The turnover of other business services, their share in services' export structure is growing. The scientific research analyses the specifics of such groups of the international services as transport and travel. However, other commercial services are analysed fragmentary enough. That is why it is urgent to identify what services could be identified as commercial. The largest group of the commercial services is other business services, which have a rather great influence on the export of the international services.

There are two viewpoints on the concept of the international service. To the first viewpoint, which is advocated by the WTO, Kelsey (2008), Cattaneo, et al. (2010), the international service attributes to the commercial services and the tradable activity. The international services include twelve groups of the services: 1) business; 2) communication; 3) construction; 4) distribution; 5) education; 6) environmental; 7) financial; 8) health related and social; 9) tourism and travel; 10) recreation; 11) transport; and 12) other services not allocated anywhere (Cattaneo, 2010). The second viewpoint relates to the commercial and non-commercial services, supplied in the international market among the residents and non-residents of the economy (International Trade in Services and Intangibles in the Era of Globalization, 2009; Manual on Statistics of International Trade in Services 2010, 2012). This classification of the international trade in services points out four groups: 1) transport; 2) travel; 3) government; and 4) other services. The difference between the two opinions is that the Governmental and other services provided by the religious organizations and missionaries, charities - do not correspond to the statistics, issued by the WTO. The commercial services include all services, excluding the services supplied for the non-commercial purposes. However, the MSITS (Manual on Statistics of International Trade in Services) approves that the international trade in services includes also non-commercial activity, not traded, but provided abroad for free. The difficulties of the measurement are related to the inappropriate statistics of services. The statistics confronts with a small part of the countries, small interest to provide the statistical data, the scarce share and unified information, etc.

Because of the above-mentioned reasons, the three groups of the international trade in services could be developed: 1) transport; 2) travel; and 3) other commercial services. It should be noticed that the structure of international trade in services depends on the economy. For example, the strongest economies' export of other commercial services made 60 percent of all export (International Trade Statistics 2012) in 2011. The travel and transport services are the dominating services in the poorest, developing countries; and other commercial services are the dominating services in the developed countries' export.

The situation is changing now. The export of the services of the developing and emerging countries follows the export of the developed economies. The international trade in services was not appreciated as an object for the international trade long enough. However, the increase of the export of the services is large. It follows the boost of the export of the merchandize (respectively 11 percent in the trade in services and 20 percent - in the merchandise, on the data of 2011) (International Trade Statistics 2012). Such countries, as India, China are large exporters of the information and communication technologies as well as related services. The Philippines and the Ukraine are large exporters of the computer services (the increase of these services was 69 percent in the Philippines and 59 percent in the Ukraine in 2011).

Research problem is formulated as several research questions: what is the expression of the transformation of the Lithuanian other business services in the international market? What changes could be observable in the structure of other business services? What is the country's competitiveness and attractiveness index, which determines the attractiveness and preconditions for the offshoring other business services in Lithuanian market?

Stating the aim of the paper: to disclose the changes of the Lithuanian international business services industry. 
Methodology: comparative analysis of the Lithuanian and EU27 countries' international business services: the structure of the international services trade, the dynamics of trade, the participation of the foreign capital in these services market, the competitiveness environment on the basis of the GCI (The Global Competitiveness Index), the attractiveness of the Lithuanian services market on the basics of the GSLI (Kearney's Global Services Location Index).

Rationale background of the research report is identified by the specifics of the Lithuanian transformation of international business services comparing them to the average of the EU. Possibilities to develop other business services industry for international market are pointed out.

\section{Method}

The purpose of the empirical research was to disclose the trends in the transformation of other Lithuanian business services, which are trade in the international market.

The classification of the international services industry is presented (see Figure 1).

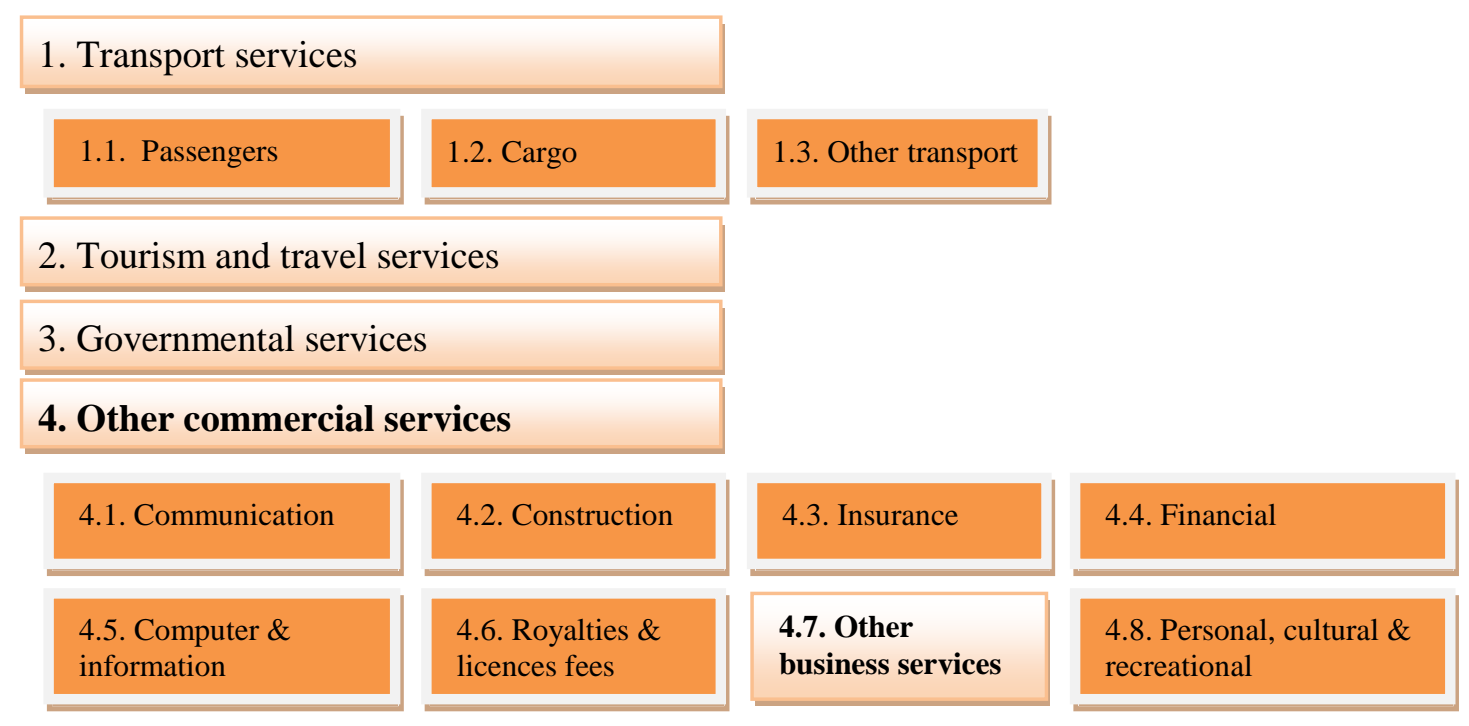

Figure 1. Other international business service in the international services industry (contributed by the authors)

The classification scheme enables to understand the place of other business services in the entire international services industry. The commercial services include group No. 1, No. 2 and No. 4; and the non-commercial services include a group No. 3. According to the MSITS, three subgroups in the industry of other international business services are identified: 1) the research and development services; 2) the professional and management consulting services; and 3) the technical, trade-related and other business services. The research and development services include the services, which are associated with the basic research, the applied research and the experimental development of the new products and processes and include the activities in physical sciences, social sciences and humanities. The professional and management consulting services are divided into two parts: a) the legal, accounting, management consulting services; and b) the public relations services and advertising, market research and public opinion polling. The technical, trade-related and other business services are grouped as follows: a) the architectural, engineering, scientific and other technical services; b) the waste treatment and de-pollution, agricultural and mining services; c) the operating leasing services; d) the trade-related services; and 5) other business services not identified earlier.

The methods of the survey: comparative qualitative analysis, descriptive statistics.

The indices representing the international trade in services were surveyed: a) the absolute change of other business services export and import of average of EU27 and Lithuania; b) the annual change mean for the other business services; c) the share of the international business services market. The calculations are made by the authors of the paper on the basis of the primary 
data of the International Trade Statistics (2013), issued by the WTO.

Analysing the structure of international services, all four groups and their subgroups are included. The role of the EU and other Lithuanian business services in the entire international services industry is evaluated. The export share and the share of Lithuanian services of the EU market, the trends of the development are estimated.

Evaluating the FDI in other business services, the trends on the basis of the indices of the international trade were estimated. The analysis of other business services FDI is not possible, as the EU, as well as the Lithuanian statistics do not provide the appropriate data. The statistics of the FDI differs as the Lithuanian statistics provide the data upon the local services' classifier, not upon the international services trade (twelve groups).

The competitiveness of the Lithuanian services market is evaluated on the GCI, estimating the rank, the worse and the best competitive factors of the market, which influence the services sector, the trade of other international business services. The sub-indexes of the GCI, as the basics requirements for the competitiveness of Lithuania, the efficiency enhancers, and the innovation as well as sophistication factors were estimated.

The dynamics of the Lithuanian GSLI, according to Kearney, was evaluated. The GSLI is calculated starting from 2007. Such sub-indexes as the financial structure (compensation costs, infrastructure costs, tax costs), the people skills and availability (cumulative business process experience and skills, labour force availability, education and language, attrition rates), and the business environment (country environment, infrastructure, cultural adaptability, security of intellectual property) are analysed.

\section{Results}

The international business services earlier were evaluated as an object for the trade only by the developed economies. Now they are the object for the trade in the emerging countries, such as India, Russia, Brazil, several post-Soviet Union countries in the EU area, and even for the countries in Africa. On the basis of the International Trade Statistics (2013) the other business services create 26 percent of the services' export and 22 percent of the import. The emerging and developing countries increase their role in the exporting the business services. However, analysing the statistical data of the WTO, we can see that half of the business services are exported from the European territory, an in major - from the countries of the EU (see Table 1).

Table 1. The changes of other business services export, by the region

\begin{tabular}{|c|c|c|c|c|c|c|c|}
\hline \multirow{2}{*}{ Export from region } & \multicolumn{2}{|c|}{ Value, milliard \$ } & \multicolumn{2}{|c|}{ Share, \% } & \multicolumn{3}{|c|}{ Annual percentage change, $\%$} \\
\hline & 2010 & 2011 & 2005 & 2011 & $2005-2011$ & 2010 & 2011 \\
\hline World & 980 & 1070 & 100 & 100 & 10 & 11 & 9 \\
\hline North America & 130 & 134 & 13.6 & 12.5 & 8 & 9 & 3 \\
\hline South and Central America & 31 & 37 & 2.4 & 3.4 & 16 & 15 & 20 \\
\hline Europe & 480 & 534 & 54.9 & 50.0 & 8 & 5 & 11 \\
\hline$E U(27)$ & 447 & 499 & 52.5 & 46.6 & 8 & 4 & 11 \\
\hline CIS & 18 & 22 & 1.2 & 2.1 & 20 & 20 & 20 \\
\hline Africa & 9 & 10 & 0.9 & 0.9 & 11 & 8 & 6 \\
\hline Middle East & 9 & 9 & $\ldots$ & 0.9 & $\ldots$ & $\ldots$ & 2 \\
\hline Asia & 300 & 323 & 25.3 & 30.2 & 13 & 24 & 8 \\
\hline
\end{tabular}

Source: International Trade Statistics 2012 (2013)

It should be noticed that a share of other business services export from the Europe and EU27 decreased since 2005. Actually the decrease of export from EU27 and Europe was similar (5.9 and 4.9 percentage points). A share of other business services international trade grew in CIS (respectively 1.2 percent was in 2005 and 2.1. per cent in 2011) and Asia (respectively 25.3 and 30.2 percent) during the same period.

The change in the export of the business services from the CIS, South and Central America is positively great (16-20 percent annually). However, we know that it will not reach the level of the 
export from the EU. It could be pointed out that European countries and especially countries of European Union are the dominating providers in other business services market.

Analysing the dynamics of other business services export of the countries of the EU and Lithuania, the absolute change is different (see Table 2). The export from the EU27 of other business services grew by 56 percent during the period, the export from Lithuania declined by 5 percent. The average change of the export was larger from the EU27 than from Lithuania (8 percent comparing to 2 percent of the export from Lithuania). The largest decrease of other business services export from the EU27 was visible in 2009. It is interesting to notice that the Lithuanian export grew in 2008-2009, but decreased in 2007, it is one year before the starting of the global financial crisis.

Table 2. The dynamics of other business services export and import, the EU vs Lithuania

\begin{tabular}{|c|c|c|c|c|c|c|c|c|c|}
\hline \multirow[b]{2}{*}{ Region } & \multicolumn{7}{|c|}{ Year } & \multirow{2}{*}{$\begin{array}{c}\text { Change } \\
\text { 2005-2011, } \\
\%\end{array}$} & \multirow{2}{*}{$\begin{array}{c}\text { Annual } \\
\text { change } \\
\text { mean } \%\end{array}$} \\
\hline & 2005 & 2006 & 2007 & 2008 & 2009 & 2010 & 2011 & & \\
\hline \multicolumn{10}{|c|}{ EXPORT } \\
\hline EU27, value million \$ & 319687 & 357237 & 433911 & 474818 & 428299 & 447212 & 498556 & 56 & \\
\hline Annual change, $\%$ & & 12 & 21 & 9 & -10 & 4 & 11 & & 8 \\
\hline $\begin{array}{c}\text { Lithuania, value } \\
\text { million \$ }\end{array}$ & 403 & 428 & 246 & 258 & 282 & 328 & 382 & -5 & \\
\hline Annual change, $\%$ & & 6 & -43 & 5 & 9 & 16 & 16 & & 2 \\
\hline $\begin{array}{c}\text { Lithuanian share of EU, } \\
\%\end{array}$ & 12.6 & 11.9 & 5.6 & 5.4 & 6.5 & 7.3 & 7.6 & & \\
\hline \multicolumn{10}{|c|}{ IMPORT } \\
\hline EU27, value million \$ & 288882 & 318725 & 387562 & 427238 & 393701 & 393192 & 433398 & 50 & \\
\hline Annual change, \% & & 10 & 22 & 10 & -8 & -1 & 10 & & 7 \\
\hline $\begin{array}{c}\text { Lithuania, value } \\
\text { million } \$\end{array}$ & 190 & 230 & 234 & 281 & 237 & 216 & 339 & 78 & \\
\hline Annual change, $\%$ & & 21 & 2 & 20 & -16 & -9 & 57 & & 13 \\
\hline $\begin{array}{c}\text { Lithuanian share of EU, } \\
\%\end{array}$ & 6.5 & 7.2 & 6.0 & 6.6 & 6.0 & 5.5 & 7,8 & & \\
\hline
\end{tabular}

Source: contributed by the authors on the data of International Trade and Market Access Data (2013)

The increase of the import of other business services was actually similar in the EU27 and Lithuania (respectively 50 and 78 percent during the surveyed period); and the import grow in Lithuania was even more rapid than in the EU27. The average annual change for the Lithuanian import was higher comparing to the change of the EU during the period (respectively 13 and 7 percent). The import of EU other business services drop in 2009 (minus 8 percent), and in 2010 ( 1 percent). The largest drop of import of other business services in Lithuania was in 2009 (minus 16 percent).

Analysing the structure of the international trade in services, it should be noticed that export of other business services from the EU27 created more than one quarter of the turnover of the international services' export (Table 3). The situation in 2011 comparing to 2005 did not changed a lot for the export of other business services (other business services' export made 26.6 percent of the export of services in 2005 and 27.6 percent in 2011). The largest change of export of services could be noticed in trading the computer and information services (105 percent grow), insurance services (74 percent) and communication services (64 percent). The share of the Lithuanian business services export's in the export of services total decreased by 6 percentage points (respectively was 12.9 percent in 2005 and 7.3 percent in 2011). The largest grow of services' export from Lithuania could be obtained for construction services (272 percent since 2005), finance services (206 percent), and personal, cultural, recreational services (110 percent). It was already mentioned above that other business services export from Lithuania decreased by 5 percent during 2005-2011. However, it should be noticed that starting from 2007 the export of other business services is growing, too. The increase of other business services export from Lithuania since 2007 is 55 percent (while increase of export of other business services export from the EU27 since 2007 is only 14 percent). 
Table 3. The international services export structure, the EU vs Lithuania

\begin{tabular}{|c|c|c|c|c|c|c|c|c|}
\hline \multirow{2}{*}{ Region } & \multicolumn{7}{|c|}{ Year } & \multirow{2}{*}{$\begin{array}{c}\text { Change } \\
2005-2011 \\
\%\end{array}$} \\
\hline & 2005 & 2006 & 2007 & 2008 & 2009 & 2010 & 2011 & \\
\hline \multicolumn{9}{|l|}{ EU27, value million \$ } \\
\hline Total services & 1201765 & 1351471 & 1633503 & 1805175 & 1565583 & 1624509 & 1803419 & 50 \\
\hline Transport & 262109 & 293880 & 354824 & 409114 & 313771 & 342357 & 372533 & 42 \\
\hline Travel & 295159 & 319673 & 364765 & 388949 & 337792 & 334732 & 377053 & 27 \\
\hline Governmental & 20915 & 21887 & 26750 & 25162 & 21648 & 21893 & 22921 & 9 \\
\hline Communication & 31859 & 36735 & 42519 & 49642 & 46246 & 47807 & 52562 & 64 \\
\hline Construction & 29280 & 33141 & 39991 & 46726 & 41434 & 38089 & 39216 & 33 \\
\hline Insurance & 22789 & 31642 & 40053 & 42416 & 39315 & 38847 & 39707 & 74 \\
\hline Finance & 94221 & 118330 & 161543 & 163141 & 131885 & 134302 & 153436 & 62 \\
\hline Computer \& information & 62503 & 73395 & 91027 & 112055 & 106644 & 113315 & 128651 & 105 \\
\hline Royalties, fees & 48899 & 51330 & 61922 & 75877 & 81437 & 85472 & 93831 & 91 \\
\hline $\begin{array}{l}\text { Personal, cultural \& } \\
\text { recreational }\end{array}$ & 14344 & 14221 & 16198 & 17275 & 17112 & 20483 & 24953 & 73 \\
\hline Other business & 319687 & 357237 & 433911 & 474818 & 428299 & 447212 & 498556 & 56 \\
\hline $\begin{array}{l}\text { Other business services, as } \\
\% \text { from total services }\end{array}$ & 26.6 & 26.4 & 26.5 & 26.3 & 27.3 & 27.5 & 27.6 & \\
\hline \multicolumn{9}{|l|}{ LITHUANIA, value million \$ } \\
\hline Total services & 3115 & 3611 & 4010 & 4747 & 3693 & 4127 & 5230 & 67 \\
\hline Transport & 1590 & 1937 & 2338 & 2875 & 2088 & 2420 & 3089 & 94 \\
\hline Travel & 923 & 1033 & 1148 & 1231 & 1005 & 1030 & 1343 & 45 \\
\hline Governmental & 35 & 33 & 37 & 62 & 55 & 60 & 54 & 54 \\
\hline Communication & 76 & 87 & 99 & 107 & 104 & 113 & 115 & 51 \\
\hline Construction & 33 & 31 & 66 & 96 & 66 & 85 & 123 & 272 \\
\hline Insurance & 0 & 0 & 0 & 5 & 0 & 1 & 0 & 0 \\
\hline Finance & 16 & 29 & 37 & 54 & 39 & 36 & 49 & 206 \\
\hline Computer \& information & 28 & 18 & 23 & 41 & 39 & 38 & 54 & 92 \\
\hline Royalties, fees & 1 & 0 & 0 & 0 & 0 & 0 & 0 & 0 \\
\hline $\begin{array}{l}\text { Personal, cultural \& } \\
\text { recreational }\end{array}$ & 10 & 15 & 16 & 18 & 15 & 16 & 21 & 110 \\
\hline Other business & 403 & 428 & 246 & 258 & 282 & 328 & 382 & -5 \\
\hline $\begin{array}{l}\text { Other business services, as } \\
\% \text { from total services }\end{array}$ & 12.9 & 11.8 & 6.1 & 5.4 & 7.6 & 7.9 & 7.3 & \\
\hline
\end{tabular}

Source: contributed by the authors on the data of International Trade and Market Access Data (2013)

Evaluating the trends of the FDI in Lithuania and the EU27, the absolute change during 20052011 of the services export was estimated. The services export as percent from the GDP grew by 3 percent in the EU while in Lithuania it did not change (0 percent) (Table 4).

Table 4. The basic indicators of the international trade, EU vs Lithuania

\begin{tabular}{|c|c|c|c|}
\hline \multirow{2}{*}{ Region } & \multirow{2}{*}{ Value 2011} & \multicolumn{2}{|c|}{ Change } \\
\hline & & $2005-2011, \%$ & $2011, \%$ \\
\hline \multicolumn{4}{|l|}{ EU27 } \\
\hline Services export, \% from GDP & 10.1 & 3 & 3 \\
\hline \multicolumn{4}{|c|}{ FDI in services - Stocks (million \$) } \\
\hline Inward & 7428377 & 9 & 2 \\
\hline Inward FDI per capita* $(\$)$ & 14783 & & \\
\hline Outward & 8180731 & 8 & 5 \\
\hline Outward FDI per capita (\$) & 16280 & & \\
\hline \multicolumn{4}{|l|}{ LITHUANIA } \\
\hline Services export, \% from GDP & 12.1 & 0 & 8 \\
\hline \multicolumn{4}{|c|}{ FDI in services - Stocks (million \$) } \\
\hline Inward & 7763 & 19 & -7 \\
\hline Inward FDI per capita $(\$)$ & 2426 & & \\
\hline Outward & 1702 & 32 & 30 \\
\hline Outward FDI per capita (\$) & 532 & & \\
\hline
\end{tabular}

Note: in the beginning of 2011 population of the EU was 502.5 million, of Lithuania - 3.2 million Source: Services Profiles Statistics (2013); Lithuania in Europe 2011 (2012) 
The FDI change in 2011 in Lithuania was higher than the average of the EU27. The FDI in the services in Lithuania grew faster than in the EU. The inward FDI grow is 19 percent since 2005 and the outward FDI is 32 percent, while the inward FDI in EU grow by 9 and outward - by 8 percent. The FDI in other business services per capita are not very consoling comparing to the EU27. The Lithuanian inward FDI differs 6 and outward - 30 times (2426 US dollars per capita for inward and 532 US dollars per capita for outward FDI, while average of the EU27 respectively is 14783 and 16280 US dollars). This means that the FDI in the Lithuanian services industry are not large estimating per capita.

Even if the statistical data are not united between Lithuanian and EU, some facts should be pointed out. Other Lithuanian business services industry does not get enough FDI. Other sectors, such as manufacturing (29.8 percent of the FDI), wholesale and retail (13.5 percent), as well as property operations (11.2 percent), financial (14.2 percent) services industry get it more. The services, which could be identified as other business services, get 3.4 percent of the FDI (the 2011 data). The situation during the last period changed a little bit as it made 2.7 percent of the FDI in 2005 (Lithuania in Europe 2011 (2012). The statistics of the EU27 points out that other business services sector absorbs 8 percent of the FDI (Foreign direct investment statistics, 2012). The situation remains to be more or less unchanged since 2005.

The GCI attributes the Lithuania to the efficiency-driven economy (The Global Competitiveness Report; 2012). Meanwhile, the majority of the EU27 members are identified as the innovation-driven economies. The different stage of the development determines the situation of other business services trade, too. The competitiveness of other Lithuanian business services is increasing through higher education and training, the efficient services, the labour market, the developed financial market, the ability of technologies, the consuming market (local and foreign). Lithuania is in the range No. 45 (the rank is 144 in total) in 2012-2013 according to the GCI. It should be pointed out that the Lithuanian competitiveness index decreased by one point per 2012 as in 2011 the country was in the position No. 44 (Table 5).

Table 5. The dynamics of the Lithuanian GCI

\begin{tabular}{|c|c|c|c|c|c|c|c|c|c|}
\hline & $\begin{array}{l}2008- \\
2009 \\
\end{array}$ & $\begin{array}{l}2009- \\
2010 \\
\end{array}$ & $\begin{array}{l}\text { Change } \\
\text { per year }\end{array}$ & $\begin{array}{l}2010- \\
2011 \\
\end{array}$ & $\begin{array}{l}\text { Change } \\
\text { per year }\end{array}$ & $\begin{array}{l}2011- \\
2012 \\
\end{array}$ & $\begin{array}{l}\text { Change } \\
\text { per year }\end{array}$ & $\begin{array}{l}2012- \\
2013 \\
\end{array}$ & $\begin{array}{l}\text { Change } \\
\text { per year }\end{array}$ \\
\hline Rank & $\begin{array}{c}44 \\
\text { (from } \\
134)\end{array}$ & $\begin{array}{c}53 \\
\text { (from } \\
\text { 133) }\end{array}$ & “_. & $\begin{array}{c}47 \\
\text { (from } \\
139 \text { ) }\end{array}$ & $"+\cdots$ & $\begin{array}{c}44 \\
\text { (from } \\
142 \text { ) }\end{array}$ & ${ }^{\prime}+{ }^{\prime}$ & $\begin{array}{c}45 \\
\text { (from } \\
144)\end{array}$ & “- 6 \\
\hline The basic requirements & 4.84 & 4.68 & “-" & 4.77 & “+” & 4.82 & "“+” & 4.84 & " $+"$ \\
\hline The efficiency enhancers & 4.37 & 4.33 & “-” & 4.28 & “-" & 4.31 & " +" & 4.38 & "+" \\
\hline The innovation factors & 3.87 & 3.75 & “-" “ & 3.79 & "++" & 3.78 & “-" “ & 3.83 & "+ +" \\
\hline Total score $(1-7)$ & 4.45 & 4.30 & "“-" & 4.38 & "+ " & 4.41 & "+"“ & 4.41 & $\begin{array}{c}\text { no } \\
\text { change }\end{array}$ \\
\hline
\end{tabular}

Source: The Global Competitiveness Report 2008-2009 (2008); The Global Competitiveness Report 2009-2010 (2009); The Global Competitiveness Report 2010-2011 (2010); The Global Competitiveness Report 2011-2012 (2011); The Global Competitiveness Report 2012-2013 (2012).

The GCI shows that the basic requirements for the competitiveness of Lithuania are evaluated 4.84 (the range No. 49 from 144). The efficiency enhancers is evaluated 4.38 (the range No. 46), and the innovation and sophistication factors -3.83 (the range No. 47). The best evaluated factors are as follows: the technological readiness of the Lithuanian people, health and primary education (score is 5-6 from 7). The market size, the financial accessibility and the innovations were evaluated worse ( 3.5 score). Evaluating the common change of the competitiveness index it should be noticed that Lithuanian score is actually the same in the surveyed period.

Analysing the changes of the Lithuanian attractiveness for the services providers according to the Kearney's index, some interesting facts should be pointed out (Table 6). 
Table 6. The dynamics of the Lithuanian Kearney's GSLI

\begin{tabular}{|c|c|c|c|c|c|}
\hline & 2007 & 2009 & $\begin{array}{c}\text { Change 2007- } \\
2009\end{array}$ & 2011 & $\begin{array}{c}\text { Change } \\
2009-2011\end{array}$ \\
\hline Rank & 28 (from 50) & 21 (from 50) & “+7” & 14 (from 50) & “+7” \\
\hline The financial attractiveness & 2.60 & 2.31 & “-” & 2.48 & “+” \\
\hline $\begin{array}{l}\text { The people and skills } \\
\text { availability }\end{array}$ & 0.83 & 0.81 & “-” & 0.93 & “+” \\
\hline The business environment & 1.98 & 1.99 & “+” & 2.02 & “+” \\
\hline $\begin{array}{rc}\text { Total score } \\
\end{array}$ & 5.42 & 5.11 & “-” & 5.43 & “+” \\
\hline
\end{tabular}

Note: Financial attractiveness has $40 \%$, people skill and availability $30 \%$, business environment $30 \%$ of GSLI. Source: Kearney (2007); Kearney (2009); Kearney (2011)

Lithuanian market is now more attractive to start a business, on the data of 2011. The Lithuanian rank in the total list of 50 countries has risen starting from 2007. The evaluation of the financial attractiveness, the people skills availability dropped in 2009. However, the common situation was better comparing to the average of the analysed countries. The changes in 2011 comparing to 2009 are positive according to all factors included in the GSLI. The evaluation of financial attractiveness increased by 0.17 , people and skill availability by 0.12 and business environment by 0.03 . This affirms that the financial attractiveness, the tax policy, the people and skills availability, and the business economic, social, cultural environment become much more attractive for the FDI, including other business services providers.

\section{Discussion}

The trade of other international business services grow already for several years. European countries are much stronger in the export of these services comparing to other countries in the world, even comparing to the countries such as North America, the emerging countries from Asia, etc. The recession influence on the export of EU of the other business services was not great, as rather clear rise of the export starting from 2005 is visible (with the exception of 2009). The Lithuanian other business services' export increased more slowly comparing to the average of the EU27. The export from Lithuania grow only starting from 2007 (the general trend still is negative one). It could be explained by the other services dominating in the Lithuanian services export structure (such as transport and tourism services). The fact that the import of the other business services to Lithuania increased more than to EU approves that these services still are not the strength point of the Lithuanian providers. It could be a reason of the increased consuming of these services in the local market, too. While the export and import of the other business services from and to EU grow similarly, the Lithuanian situation is totally different: the import of the services grows more quickly than in EU27, but export change during analysed period is negative. The share of the business services export in the total EU export structure shows that these services make a large part of the exportable services. The Lithuanian other business services creates a small part. The export of the other business services from Lithuania is getting more percentage points only starting from 2009.

The transformation in the FDI in the services sector shows that the situation in the Lithuanian services sector improves quicker than in the EU. Even if the outward and the inward FDI per capita in Lithuania are behind the EU, general trends are rather well. That shows that the Lithuanian services sector is attractive for the foreign investors. The Lithuanian services business providers are making actions in the foreign markets, too. The GCI shows that the Lithuanian rank according to the competitive factors is practically the same already for several years. Evaluating the attractiveness of Lithuania for the foreign investors, it should be pointed out that the financial attractiveness, the people and their skills availability, the business environment are evaluated better; what is approved by the improved rank of Lithuania (14 in 2011) for offshoring services providers. The strong people skills allows to develop small business services companies, which are ready to supply services, called as other business services, both for the local or foreign customer. The 
Lithuanian business environment comparing to EU27 is favourable enough. However, the reality shows a lot of samples when the Lithuanian business services companies are establishing abroad in order to decrease taxes, to shorten business procedures.

The further research could include the more detailed data analysis, developing three subcategories of other business services and their changes in the economy: 1) the research and development; 2) the professional and management consulting; 3) the technical, trade-related and other business services. As the knowledge intensive business services create the future for the innovation-driven economy - the local services providers should think about the possibilities to improve the Lithuanian position in the EU other business services market.

\section{References}

Alexander, N., Rhodes, M. \& Myers, H. (2007). International market selection: measuring actions instead of intentions. Journal of Services Marketing, 21(6), 424-434.

Bhagwati, J. (1987). International trade in services and its relevance for economic development. In Orio Giarini (ed.), The Emerging Services Economy. Services World Economy Series 1. New York: Pergamon Press.

Cattaneo, O., Engman, M., Sáez, S. \& Stern, R. M. (2010) Assessing the potential of services trade in developing countries: an overview, 1-28. In International trade in services: new trends and opportunities for developing countries. Ed. Engman, M., et al. The World Bank.

Dixel, N., Eschenbach, F. \& Shepherd, B. (2008). South - South services trade, pp. 23-76. In GATS and the regulation of International Trade in Services. Panizzon, M.; Pohl, N.; Sauvé, P., eds. Cambridge University Press.

Foreign direct investment statistics (2012). Eurostat information, Main tables and Database. Retrieved February 28, 2013, from: http://epp.eurostat.ec.europa.eu.

Global Services Location Index (2013). Global Business Policy Council. Retrieved March 13, 2013, from: http://www.atkearney.com/gbpc/global-services-location-index.

Hertel, T. W., Anderson, K., Francois, J. F. \& Martin, W. (2000). Agricultural and Non-agricultural Liberalization in the Millennium Round. Policy Discussion Paper, No. 0016, 4-47.

International Trade and Market Access Data (2013). World Trade Organization, Statistics, Database. Retrieved March 1, 2013, from: http://www.wto.org.

International trade in services and intangibles in the era of globalization (2009). Ed. By Reinsdorf, M.; Slaughter, M. J., the National Bureau of Economics research, Studies in Income and Wealth, Vol. 69.

International Trade Statistics 2012 (2013). World Trade Organization.

Jansen, J. \& Stokman, A. (2011). International Business Cycle Comment: Trade and Foreign Direct Investment, DNB Working Papers 319, Netherlands Central Bank, Research Department.

Karsenty, G. (2000). Assessing Trade in Services by Mode of Supply, in GATS 2000 - new directions in services trade liberalization, P. Sauve, R. M. Stern, eds. The Brookings institution, 33-113.

Kearney, A. T. (2007). Offshoring for Long-term Advantage: A. T. Kearney Global Services Location Index. Retrieved March 13, from: http://www.atkearney.com/gbpc/global-services-location-index.

Kearney, A. T. (2009). The Shifting Geography of Offshoring: The 2009 A. T. Kearney Global Services Location Index. Retrieved March 13, from: http://www.atkearney.com/gbpc/global-services-locationindex.

Kearney, A. T. (2011). Offshoring Opportunities Amid Economic Turbulence: The A. T. Kearney Global Services Location Index, 2011. Retrieved April 8, from: http://www.atkearney.com/gbpc/globalservices-location-index.

Kelsey, J. (2008). Serving Whose Interest? The political economy of trade in services agreements. Routledge-Cavendish. A Glass-House book.

Lithuania in Europe 2011 (2012). Statistics Lithuania.

Love, P. \& Lattimore, R. (2009). International trade: free, fair and open? OECD publications.

Manual on Statistics of International Trade in Services 2010 (2012). Department of Economic and Social Affairs, Statistics Division. United Nations Publication, New York. 
McGuire, G. (2002). Trade in Services: Market Access Opportunities and the Benefits of Liberalization for Developing Economies. UN, New York and Geneva.

Services Profiles Statistics (2013). World Trade Organization. Retrieved February 28, 2013, from: http://stat.wto.org.

Spring, M. \& Araujo, L. (2010). Service, services and products: rethinking operations strategy. International Journal of Operations \& Production Management, 29(5), 444-467.

The Global Competitiveness Report 2008-2009 (2008). Ed. by Schwab K. published by the World Economic Forum within the framework of the Global Competitiveness Network.

The Global Competitiveness Report 2009-2010 (2009). Ed. by Schwab K. published by the World Economic Forum within the framework of the Global Competitiveness Network.

The Global Competitiveness Report 2010-2011 (2010). Ed. by Schwab K. published by the World Economic Forum within the framework of the Global Competitiveness Network.

The Global Competitiveness Report 2011-2012 (2011). Ed. by Schwab K. published by the World Economic Forum within the framework of the Global Competitiveness Network.

The Global Competitiveness Report 2012-2013 (2012). Ed. by Schwab, K. Full Data Edition is published within the framework of The Global Benchmarking Network. 